\title{
Biochemical changes during ripening of cheeses in an animal skin
}

\author{
Milna Tudor Kalit ${ }^{1 *}$, Tihana Lojbl ${ }^{1}$, Ante Rako², \\ Ilhan Gün³ , Samir Kalit ${ }^{7}$
}

\begin{abstract}
'University of Zagreb, Faculty of Agriculture, Department of Dairy Science, Svetošimunska 25, Zagreb, Croatia Institute for Adriatic Crops and Karst Reclamation, Put Duilova 11, Split, Croatia

${ }^{3}$ Mehmet Akif Ersoy University, Burdur Vocational School, Food Processing Department,

Milk and Milk Products Programme, İstiklal Campus, 15100, Burdur, Turkey

*Corresponding author: mtudor@agr.hr
\end{abstract}

\section{Abstract}

A few types of cheeses ripened in an animal skin sack are produced around the world: Sir iz mišine (Croatia), Sir iz mijeha (Bosnia and Herzegovina and Montenegro), Tulum and Divle Cave (Turkey), Bouhezza (Algeria) and Darfiyeh (Lebanon). Pronounced and piquant taste, flavour and aroma of these cheeses originate from intensive lipolysis and proteolysis as a result of specific anaerobic conditions inside the skin sack, autochthonous microorganisms from raw milk and skin, as well as their manufacturing procedure. The specific and complex biochemical changes that occur during ripening of cheeses in animal skin sacks have become of great interest to researchers, and numerous studies have been conducted over the last decade. Therefore, the aim of this paper is to review the specificities of proteolytic and lipolytic changes that occur during ripening of cheese in the animal skin sack, which cause the characteristic volatile compounds profile. Moreover, the manufacturing procedures and physico-chemical properties of cheeses is shown due to their relationship with biochemical reactions during cheese ripening. As biochemical changes during ripening directly influence sensory attributes of cheese, which determine consumer preference, this review could provide practical data for cheesemakers to prevent negative consequences of overly intensive biochemical changes during cheese ripening, and so improve the quality of this kind of cheeses.

Key words: animal skin sack, cheese ripening, biochemical changes, proteolysis, lipolysis, volatile compounds 


\section{Introduction}

The ripening process of a cheese consists of biochemical and microbiological changes, the interaction of which leads to the specific sensory properties of a cheese. Microbiological changes include the death (autolysis) of the lactic acid bacteria, as well as the growth of other non-starter microbial populations and the secondary microflora, whose enzymes during biochemical changes of cheese ripening process degrade the complex organic compounds into simpler ones which leads to the formation of a specific cheese texture, flavour and aroma (Upadhyay et al., 2004; McSweeney, 2004; Simsek et al., 2016). Cheeses ripened in an animal skin sack have a pronounced and piquant flavour, odour and aroma and a specific granulated or spreadable and smooth texture. These cheese characteristics are clearly different in comparison to the cheeses ripened in a natural rind, due to the specific biochemical processes of proteolysis and lipolysis that take place during ripening in the animal skin sack under specific conditions. This includes anaerobic conditions inside the skin sack, which means less air permeability in comparison to a natural rind of the cheese, but greater permeability in comparison to plastic barrels which are also sometimes used as a medium for ripening this type of cheese (Tudor Kalit, 2014.). Animal skin should be prepared using a particular technique in which it is necessary not to damage the skin, in order to ensure the anaerobic conditions of the entire ripening process (Tudor Kalit et al., 2010). Naturally present population of lactic acid bacteria and other non-starter bacteria, as well as secondary microflora (yeasts and moulds), are responsible for the specific properties of cheeses ripened in the animal skin (Hayaloglu et al., 2007; Tudor Kalit et al., 2010; Lešić et al., 2016; Medjoudj et al., 2017a). Due to the intense biochemical processes during ripening in the animal skin, it is necessary to pay attention to the quality of milk, when heat treatment of milk is not applied (Frece at el., 2016).

A few types of cheeses ripen in an animal skin sack are produced around the world. They differ in the manufacturing procedure and the type of milk used. Cheeses ripened in animal skin are produced in Croatia (Sir iz mišine), Bosnia and Herzegovina and Montenegro (Sir iz mijeha), Turkey (Tulum and Divle Cave), Algeria (Bouhezza) and Lebanon (Darfiyeh).
The aim of this paper is to review the specificities of proteolytic and lipolytic changes that occur during ripening of cheese in the animal skin sack, which cause the characteristic volatile compounds profile. Moreover, the manufacturing procedures and physico-chemical properties of these cheeses are shown due to their relationship with biochemical reactions during cheese ripening.

\section{Manufacturing procedures}

Cheeses that ripen in an animal skin sack belong to the group of traditional cheeses characterized by a strong connection to the culture and history of the country of their origin. The main specificity of these cheeses is ripening in a sack made of the whole lamb or goat body skin, which have different regional and local names: mišina (Croatia), mijeh (Bosnia and Herzegovina and Montenegro), tulum (Turkey), chekoua (Algeria). Tables 1 and 2 show the manufacturing procedures of cheeses that ripen in animal skin sack.

Proper preparation of skin for cheese ripening is an important process in cheese production. It ensures the correct ripening process under anaerobic conditions during which unique sensory characteristics of this kind of cheese are formed. The type of skin as well as the skin processing are different among traditional cheeses that ripen in animal skin sack. Turkish Tulum cheese generally matures in goatskin without hair. However, in some Turkish regions unprocessed skin is used (Kamber, 2008.). Medjoudj et al. (2017b) reported that in production of Bouhezza cheese goat skin is used, with its outer layer (wool side) in contact with the cheese. In the production process of the Croatian Sir iz mišine the way of using a skin is not uniform. Some producers make the skin sack so the outer layer of the skin is in contact with the cheese, and others in the way that cheese is in contact with the inner side of skin (the part of skin near the meat) (Tudor Kalit et al., 2010).

The animal skin consists of fibrous proteins such as collagen, elastin, reticulin and keratin, therefore the properties of skin is different in different parts of the body. This affects the air and water vapour permeability of the animal skin sack, which significantly affect chemical and biochemical properties and aroma compounds of cheese during ripening (Harmancıoglu, 1998; Gün et al., 2015), as well 
as an animal species and the age of animal which is used for skin sack production. Water vapour and air permeability of goat skins differ from the sheep skins due to their thicker and more sebaceous structure (Gün and Guzel-Seydim, 2011). Gün et al. (2015) reported that a good quality Tulum cheese is produced when using a 6-month-old or 1-year-old female goat skin (Gün et al., 2015).

The skin preparation requires a special technique in which it is important to avoid any damage of the skin during wool and meat removal (Fig. 1). A wrong technique of skin preparation can lead to skin tears, and consequently air inlet, which can cause cheese spoiling (Tudor Kalit et al., 2010). Skin inspection for occurrence of cracks is done by filling the skin sack with air when skin openings are tightened with ropes (Fig. 2). After this procedure, the skin is washed and dried in the wind or smoked. Before filling with cheese, the skin is soaked in warm water or whey (Tudor Kalit et al., 2010) or in salted (5 \%) water (Sert et al., 2014), and all skin openings are disinfected with vinegar or a traditional alcoholic drink called rakija (Tudor Kalit et al. 2010). According to Medjoudju et al. (2017a), Bouhezza cheese matures in goat skin which is preserved with salt and juniper because of its antiseptic and antifungal properties. Furthermore, juniper is also used to eliminate unpleasant skin odour.

Sir iz mišine belongs to the group of traditional Croatian cheeses with a long tradition of production in Dalmatia, the special feature of which is dry and hot sub-Mediterranean and Mediterranean climate and hilly terrain configuration with the specific botanical composition of a wide range of Mediterranean species. According to historical data,

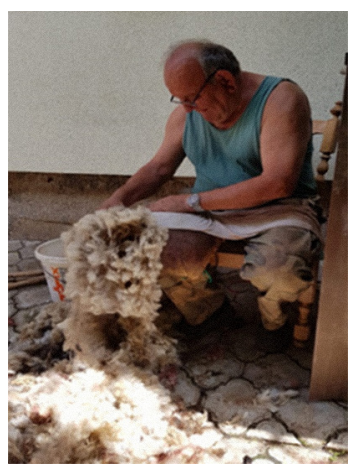

FIGURE 1. Animal skin processing (source: Petrović, I.)

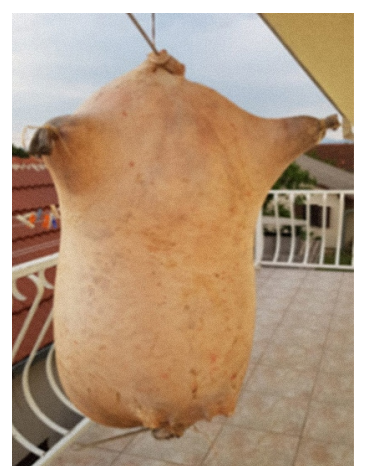

FIGURE 2. Animal skin sack filled with air (source: Petrović, I.) the production of Sir iz mišine started in the period of Illyrians and Thracians. They grazed their sheep in the pastures of mountain Dinara and used lamb skin for storage and transport of cheese from the mountain to the valley. Usually, it is produced on small family farms with their own livestock for the production of milk. To a lesser extent Sir is mišine is produced from pasteurised milk in industrial conditions using mesophilic dairy cultures (Kalit, 2016; Barukčić and Tudor Kalit, 2019).

Sir iz mijeha is a traditional cheese produced in Herzegovina and the time of its genesis coincides with the genesis of Croatian Sir iz mišine, while their manufacturing procedure is very similar too. The main difference is reflected in the step of temporary storage of salted cheese in a wooden vat (usually under pressure) after draining, in case there is not enough cheese produced in one day for filling the sack. During that time, an aerobic phase takes place, in which lactic acid bacteria intensively convert lactose to lactic acid. In addition, the form and texture is different from the Croatian variety. Sir iz mijeha is broken by hand into irregularly shaped pieces before putting into the skin sack and therefore has crumbly texture as opposed to the Croatian cheese, which is compact and easy to cut (Bijeljac, 2004; Bijeljac and Sarić, 2005; Tudor Kalit et al., 2010; Samardžić et al., 2014).

In Turkey, there is a large number of cheeses matured in an animal skin, the best known being Tulum cheese. There are several varieties of Tulum cheese such as Erzincan (Savak) tulum, Divle tulum, Izmir brined tulum and Cimi tulum cheese. Erzincan (Savak) tulum cheese is the best known variant of Tulum cheese. Today, it is produced in all regions of Turkey. The name of this cheese comes from a nomadic tribe (Savak) that used to live in Eastern Turkey, more precisely in the province of Erzincan in the Anatolian region. Production has been carried out in smaller dairies and on family farms using traditional methods, and to a lesser extent under industrial conditions using modern production methods (CeyIan et al., 2007; Sert et al., 2014). Tulum cheese is generally made from semi-skimmed milk. However, in the traditional production skimmed ewe's milk remaining after butter production is used very often (Sert et al., 2014). Some producers sometimes add yoghurt during production to achieve a better and more pronounced cheese flavour (Kamber, 2008). 
In a modified process of Tulum cheese production, plastic containers can be used instead of animal skin to prevent possible contamination (Colak et al., 2007). Izmir Brined Tulum cheese produced in the Aegean region of Turkey is a specific variety. After pressing the cheese, it is not broken by hand, but the whole blocks are placed into the skin sack, dry salted, brined and ripened at $+4{ }^{\circ} \mathrm{C}$ (Durlu Özkaya and Gün, 2016; Akpinar et al., 2017). Divle Cave cheese is produced in central Turkey. This is a semihard cheese usually made from raw semi-skimmed ewe's milk and ripened in goat skin sack in natural caves called obruk which means skinhole (İsleyici et al., 2018). Ripening takes places at a depth of 70 $\mathrm{m}$ at a temperature of $5-10^{\circ} \mathrm{C}$ and humidity of $85-$ $90 \%$. It lasts 4 months during which the skin takes on a reddish-green colour, which makes Divle Cave cheese specific compared to other cheeses that are ripened with spontaneous mould growth, such as Kuflu cheese (Ozturkoglu-Budak et al., 2016b). It is considered ready to eat when those moulds begin to fall off (Watson, 2016).

Darfiyeh cheese is produced in Lebanon in the northern mountainous region characterised by traditional goat breeding and goat milk production (Serhan et al., 2009; Serhan and Mattar, 2017). After the production of Darfiyeh cheese residual curd is used for the production of whey cheese called Arichi, which ripens in goat skin sacks together with Darfiyeh cheese. 2-3 Darfiyeh cheese balls are placed in the skin, followed by a fistful of Arichi cheese. Salting of Arichi cheese with $1 \mathrm{~kg} \mathrm{NaCl}-\mathrm{a}$ is of extreme importance, considering that Darfiyeh cheese is not salted during production, and that the salt diffuses from whey cheese to Darfiyeh cheese during the ripening process. An interesting feature in the production of Darfiyeh is the weekly salting of goatskin with $5 \mathrm{~kg}$ of salt (Serhan et al., 2010).

Bouhezza is an Algerian cheese whose production is related to the north-east of the country. Its production is specific compared to the other cheeses ripened in the animal skin. It belongs to the group of soft cheese considering that it is produced by a spontaneous fermentation process lasting 24 36 hours at room temperature of $25-30{ }^{\circ} \mathrm{C}$. The fermented milk called Rayeb is churned for 30-45 minutes together with $0.25 \mathrm{~L}$ of warm water (20$25^{\circ} \mathrm{C}$ ) in order to promote the gathering of butter grains, which facilitates the skimming. After a partial skimming, the recovered product called Lben is put into the skin in an amount of 2-3 L and left overnight to reduce the intense smell of goat skin, after which it is replaced by Lben previously salted with $20-25 \mathrm{~g} / \mathrm{L}$ salt. On the first day, chekoua is filled with 3 litres of salted Lben, and then refilled every 3-4 days with 2-2.5 $L$ of Lben. Two weeks before production ends, chekoua is filled with $2 L$ of raw milk at four intervals. When the ripening process is completed, cheese is spiced with red pepper, which gives it a piquant flavour, white colour and a pasty consistency with a red dots of hot pepper (Aissaoui Zitoun et al., 2012; Medjoudj et al., 2017b).

Significant differences in the physico-chemical composition of cheeses are the result of the different manufacturing procedures and different composition of the milk used for the cheese production, depending on the type of milk and animal breed (Table 2).

\section{Proteolysis}

Primary proteolysis involves the initial degradation of the para-casein network with chymosin activity and, to a lesser extent, plasmin activity (Sousa et. al., 2001), which results in forming medium and low molecular weight fractions that contribute to cheese aroma and texture (Havranek et al. 2014; Rako et al., 2019). During the ripening of Sir iz mišine the hydrolysis of $a_{51}$-casein is more intense than the hydrolysis of $\beta$-casein, resulting in accumulation of $\mathrm{a}_{\mathrm{s} 1}$-l-casein (increase of $4 \%$ after 30 days of ripening). Although the degradation of $\beta$-casein is not noticeable, the concentration of $\gamma$-casein increases significantly during ripening ( $8.51 \%$ at beginning of the ripening, $18.14 \%$ after 30 days of ripening; Rako et al., 2019). Celik and Tarakci (2017) reported similar findings in their research of the influence of different starter cultures on proteolysis during ripening of Tulum cheese. Together with residual rennet, protease/peptidase of bacteria in the composition of the starter culture play an important role in $\mathrm{a}_{\mathrm{S} 1}$-casein degradation. Since there is no significant degradation of $\beta$-casein in both studies, it can be concluded that residual rennet and protease/peptidase of starter culture play a dominant role in proteolytic process during cheese ripening, compared to plasmin. 
TABLE 1. The manufacturing procedures of cheeses ripened in animal skin

\begin{tabular}{|c|c|c|c|c|c|c|}
\hline & $\begin{array}{l}\text { Sir iz mišine } \\
\text { (Croatia) }\end{array}$ & $\begin{array}{l}\text { Sir iz mijeha } \\
\text { (Bosnia and } \\
\text { Herzegovina) }\end{array}$ & $\begin{array}{l}\text { Tulum } \\
\text { (Turkey) }\end{array}$ & $\begin{array}{l}\text { Darfiyeh } \\
\text { (Lebanon) }\end{array}$ & $\begin{array}{l}\text { Divle Cave } \\
\text { (Turkey) }\end{array}$ & $\begin{array}{l}\text { Bouhezza } \\
\text { (Algeria) }\end{array}$ \\
\hline Type of milk & $\begin{array}{l}\text { Ewe, goat, } \\
\text { cow and their } \\
\text { mixture, full } \\
\text { fat }\end{array}$ & $\begin{array}{l}\text { Ewe, cow and their } \\
\text { mixture, skimmed } \\
\text { or semi-skimmed }\end{array}$ & $\begin{array}{l}\text { Ewe, goat, cow, } \\
\text { buffalo and their } \\
\text { mixture, full-fat, } \\
\text { semi-skimmed and } \\
\text { skimmed }\end{array}$ & Goat, full fat & $\begin{array}{l}\text { Ewe, semi- } \\
\text { skimmed }\end{array}$ & $\begin{array}{l}\text { Ewe, goat, cow, } \\
\text { semi-skimmed }\end{array}$ \\
\hline Coagulation & $\begin{array}{l}\text { Heating of } \\
\text { milk (32-37 } \\
\left.{ }^{\circ} \mathrm{C}\right) \text {, addition } \\
\text { of rennet and } \\
\text { coagulation } \\
\text { (30-50 min) }\end{array}$ & $\begin{array}{l}\text { Heating of } \\
\text { milk }\left(32-37^{\circ} \mathrm{C}\right) \text {, } \\
\text { addition of rennet } \\
\text { and coagulation } \\
\text { (30-50 min) }\end{array}$ & $\begin{array}{l}\text { Heating of milk } \\
\left(30-35^{\circ} \mathrm{C}\right) \text {, addition } \\
\text { of rennet and } \\
\text { coagulation } \\
\text { (90-180 min) }\end{array}$ & $\begin{array}{l}\text { Heating } \\
\text { of milk } \\
\left(30-355^{\circ} \mathrm{C}\right) \text {, } \\
\text { addition of } \\
\text { rennet and } \\
\text { coagulation } \\
\text { (60-90 min) }\end{array}$ & $\begin{array}{l}\text { Heating of } \\
\text { milk }(30 \\
\left.\text { to } 32^{\circ} \mathrm{C}\right) \text {, } \\
\text { addition of } \\
\text { rennet and } \\
\text { coagulation } \\
\text { (80 min) }\end{array}$ & $\begin{array}{l}\text { Spontaneous } \\
\text { acid } \\
\text { fermentation } \\
\left(25-30^{\circ} \mathrm{C} /\right. \\
24-36 \mathrm{~h})\end{array}$ \\
\hline $\begin{array}{l}\text { Cutting the } \\
\text { curd }\end{array}$ & $\begin{array}{l}\text { Irregular size } \\
3 \times 3 \mathrm{~cm}\end{array}$ & $\begin{array}{l}\text { Irregular size } \\
3 \times 3 \mathrm{~cm}\end{array}$ & Cubes $1-2 \mathrm{~cm}^{3}$ & $\begin{array}{l}\text { Medium } \\
\text { size cubes }\end{array}$ & $\begin{array}{l}\text { Small size } \\
\text { cubes }\end{array}$ & - \\
\hline $\begin{array}{l}\text { Heating the } \\
\text { curd grain }\end{array}$ & $\begin{array}{l}35-40^{\circ} \mathrm{C} / \\
20-30 \mathrm{~min}\end{array}$ & $\begin{array}{l}35-40{ }^{\circ} \mathrm{C} / \\
20-30 \mathrm{~min}\end{array}$ & $\begin{array}{l}30-35^{\circ} \mathrm{C} / 10-30 \mathrm{~min} \\
\text { or } 50^{\circ} \mathrm{C} / 12-15 \mathrm{~min}\end{array}$ & $\begin{array}{l}30-35^{\circ} \mathrm{Cl} \\
20 \min \end{array}$ & $\begin{array}{l}55 \text { to } 60^{\circ} \mathrm{C} \\
/ 4-5 \min \end{array}$ & - \\
\hline $\begin{array}{l}\text { Shaping the } \\
\text { curd grain }\end{array}$ & $\begin{array}{l}\text { Harvest by } \\
\text { hand and put } \\
\text { in the cotton } \\
\text { cloth }\end{array}$ & $\begin{array}{l}\text { Harvest by hand } \\
\text { and put in the } \\
\text { cotton cloth }\end{array}$ & $\begin{array}{l}\text { Harvest by hand and } \\
\text { put in the cotton } \\
\text { cloth }\end{array}$ & $\begin{array}{l}\text { Shaping } \\
\text { into cheese } \\
\text { balls ( } 400- \\
500 \mathrm{~g})\end{array}$ & $\begin{array}{l}\text { Harvest } \\
\text { by hand } \\
\text { and put in } \\
\text { the cotton } \\
\text { cloth }\end{array}$ & - \\
\hline Pressing & Self-pressing & $\begin{array}{l}\text { Under pressure } \\
2-4 \text { hours }\end{array}$ & $\begin{array}{l}3 \text { times: self-pressing } \\
\text { and two times under } \\
\text { pressure }\end{array}$ & - & $\begin{array}{l}\text { Under } \\
\text { pressure } \\
2-3 \text { hours }\end{array}$ & - \\
\hline $\begin{array}{l}\text { Salting and } \\
\text { preparing } \\
\text { for the } \\
\text { putting in } \\
\text { the skin } \\
\text { sack }\end{array}$ & $\begin{array}{l}\text { Cutting into } \\
\text { pieces } 10 \\
\times 10 \times 5 \mathrm{~cm} \\
\text { in size, dry } \\
\text { salted }\end{array}$ & $\begin{array}{l}\text { Salted, stored } \\
\text { in the wooden } \\
\text { vat for } 1-2 \text { days, } \\
\text { broken into small } \\
\text { irregular shaped } \\
\text { pieces (crumbling) } \\
\text { by hand, salted } \\
\text { again }\end{array}$ & $\begin{array}{l}\text { Dry salted of curd } \\
\text { in cheese cloth after } \\
2^{\text {nd }} \text { pressing, broken } \\
\text { by hand into small } \\
\text { irregular shaped } \\
\text { pieces (crumbling) } \\
\text { after } 3^{\text {rd }} \text { pressing }\end{array}$ & $\begin{array}{l}\text { Not salted } \\
\text { (it is ripened } \\
\text { together } \\
\text { with whey } \\
\text { cheese } \\
\text { Arichi which } \\
\text { is salted) }\end{array}$ & $\begin{array}{l}\text { Broken into } \\
\text { small } \\
\text { pieces by } \\
\text { hand, dry- } \\
\text { salted }\end{array}$ & $\begin{array}{l}\text { Fermented } \\
\text { milk is salted } \\
(25 \mathrm{~g} \text { salt } / \mathrm{L})\end{array}$ \\
\hline Ripening & $\begin{array}{l}2-3 \text { months } \\
(65-80 \% \\
\text { air humidity, } \\
\left.18-20^{\circ} \mathrm{C}\right)\end{array}$ & $\begin{array}{l}2-3 \text { months } \\
(85 \% \text { air humidity, } \\
\left.12-15^{\circ} \mathrm{C}\right)\end{array}$ & $\begin{array}{l}3-6 \text { months } \\
(65-85 \% \text { air humidity, } \\
\left.6-10{ }^{\circ} \mathrm{C}\right)\end{array}$ & $\begin{array}{l}1-3 \text { months } \\
(85-95 \% \\
\text { air humidity, } \\
\left.10-12{ }^{\circ} \mathrm{C}\right)\end{array}$ & $\begin{array}{l}4 \text { months } \\
\text { in the cave } \\
(85-90 \% \\
\text { air humidity, } \\
5-10^{\circ} \mathrm{C} \text { ) }\end{array}$ & 2-3 months \\
\hline $\begin{array}{l}\text { Appearance } \\
\text { and/or } \\
\text { texture after } \\
\text { ripening }\end{array}$ & $\begin{array}{l}\text { Irregular } \\
\text { shaped } \\
\text { pieces, hard } \\
\text { texture }\end{array}$ & Crumbly & Crumbly & $\begin{array}{l}\text { Shape of } \\
\text { balls, semi- } \\
\text { hard texture }\end{array}$ & Crumbly & $\begin{array}{l}\text { Spreadable } \\
\text { paste, } \\
\text { smooth, firm } \\
\text { and sticky }\end{array}$ \\
\hline $\begin{array}{l}\text { Literature } \\
\text { source }\end{array}$ & $\begin{array}{l}\text { Tudor Kalit et } \\
\text { al. (2014) }\end{array}$ & Bijeljac (2004) & Sert et al. (2014) & $\begin{array}{l}\text { Serhan et } \\
\text { al. (2010); } \\
\text { Serhan } \\
\text { and Mattar } \\
(2017)\end{array}$ & $\begin{array}{l}\text { Ozturkoglu- } \\
\text { Budak et al. } \\
\text { (2016b) }\end{array}$ & $\begin{array}{l}\text { Medjoudj et } \\
\text { al. (2017a); } \\
\text { Aissaoui } \\
\text { Zitoun et al. } \\
(2011)\end{array}$ \\
\hline
\end{tabular}


TABLE 2. Average physico-chemical composition of the cheeses ripen in an animal skin at the end of the ripening process

\begin{tabular}{|c|c|c|c|c|c|c|c|c|c|c|}
\hline & $\begin{array}{l}\text { Sir iz mijeha } \\
\text { (Bosnia and } \\
\text { Herzegovina) }\end{array}$ & $\begin{array}{l}\text { Sir iz } \\
\text { mišine } \\
\text { (Croatia) }\end{array}$ & $\begin{array}{l}\text { Sir iz } \\
\text { mišine } \\
\text { (Croatia) }\end{array}$ & \begin{tabular}{|l} 
Tulum \\
(Turkey)
\end{tabular} & $\begin{array}{l}\text { Tulum } \\
\text { (Turkey) }\end{array}$ & $\begin{array}{l}\text { Tulum } \\
\text { (Turkey) }\end{array}$ & $\begin{array}{l}\text { Tulum } \\
\text { (Turkey) }\end{array}$ & $\begin{array}{l}\text { Divle } \\
\text { Cave } \\
\text { (Turkey) }\end{array}$ & $\begin{array}{l}\text { Darfiyeh } \\
\text { (Lebanon) }\end{array}$ & $\begin{array}{l}\text { Bouhezza } \\
\text { (Algeria) }\end{array}$ \\
\hline Milk type & ewe & ewe & ewe & cow & cow & goat & ewe & ewe & goat & goat \\
\hline $\begin{array}{l}\text { Maturity } \\
\text { of cheese } \\
\text { (days) }\end{array}$ & different & 60 & 30 & 90 & 270 & 360 & 90 & 120 & 60 & 64 \\
\hline $\begin{array}{l}\text { Total } \\
\text { solids (\%) }\end{array}$ & 78.98 & 64.97 & 58.20 & 59.34 & 70.19 & 63.00 & 69.36 & 53.61 & - & 30.60 \\
\hline $\begin{array}{l}\text { Proteins } \\
(\%)\end{array}$ & 31.17 & 23.93 & 22.18 & 24.22 & 26.99 & - & 28.10 & 29.54 & 36.72 & 15.65 \\
\hline Fat (\%) & 39.40 & 34.53 & 31.28 & 26.25 & 38.75 & 29.00 & 33.85 & 18.67 & - & 35.62 \\
\hline $\begin{array}{l}\text { Fat in } \\
\text { total } \\
\text { solids (\%) }\end{array}$ & 49.54 & 52.96 & - & 44.24 & 55.20 & 46.00 & - & 34.55 & 43.46 & - \\
\hline $\begin{array}{l}\text { Moisture } \\
\text { in solids- } \\
\text { nonfat } \\
(\%)\end{array}$ & - & 53.30 & 60.77 & - & - & - & - & - & 54.15 & - \\
\hline $\mathrm{NaCl}(\%)$ & - & 2.46 & 1.91 & 4.92 & $8.92^{*}$ & 6.20 & 5.34 & 3.80 & & \\
\hline $\mathrm{pH}$ & - & 5.15 & 5.20 & 5.42 & - & 4.98 & - & 5.06 & 4.99 & 3.99 \\
\hline Ash & 4.44 & - & - & - & - & 8.80 & 7.12 & - & - & 1.24 \\
\hline $\begin{array}{l}\text { Literature } \\
\text { source }\end{array}$ & $\begin{array}{l}\text { Dozet et al. } \\
\text { (1996) }\end{array}$ & $\begin{array}{l}\text { Tudor } \\
\text { Kalit } \\
\text { et al. } \\
(2014)\end{array}$ & $\begin{array}{l}\text { Rako } \\
\text { et al. } \\
\text { (2019) }\end{array}$ & $\begin{array}{l}\text { Sengul } \\
\text { et al. } \\
(2014)\end{array}$ & $\begin{array}{l}\text { Tekin } \\
\text { and } \\
\text { Güler } \\
\text { (2019) }\end{array}$ & $\begin{array}{l}\text { Sert } \\
\text { et al. } \\
(2014)\end{array}$ & $\begin{array}{l}\text { Ceylan } \\
\text { et al. } \\
(2007)\end{array}$ & $\begin{array}{l}\text { Ozturko- } \\
\text { glu-Budak } \\
\text { et al. } \\
\text { (2016b) }\end{array}$ & $\begin{array}{l}\text { Serhan et } \\
\text { al. (2010) }\end{array}$ & $\begin{array}{l}\text { Medjoudj } \\
\text { et al. } \\
(2017 a)\end{array}$ \\
\hline
\end{tabular}

*Salt-in moisture

That could be expected considering the fact that the optimal $\mathrm{pH}$ for plasmin activity is 7.5 and the salt content less than $2 \%$ (Upadhyay et al., 2004). The increased $\mathrm{pH}$ value due to lactate metabolism and ammonia formation as a result of advanced proteolysis improves the activity of plasmin during cheese ripening (Hayaloglu and Ozer, 2011). A larger part of the added rennet used in the production of Sir iz mišine stays in whey, as $60.66 \%$ $\mathrm{a}_{\mathrm{s} 1}$-casein and $90.49 \%$-casein remain intact at the end of the ripening period (Rako et al., 2019). Celik and Tarakci (2017) obtained similar results for $\beta$-casein $(90.14 \%)$ in the research on Tulum cheese, while the result for $\mathrm{a}_{\mathrm{s} 1}$-casein (84.96\%) is higher in comparison to the Sir iz mišine. Sengül et al. (2014) claim that use of microbial rennet results in intensive $a_{51}$-casein and $\beta$-casein degradation. After 90 days of Tulum cheese ripening, in the production of which microbial rennet (protease Aspergillus niger and Rhizomucor miehei) was used, the value of $\mathrm{a}_{\mathrm{s} 1}$-casein $(50.59 \%, 50.32 \%$, respectively) and $\beta$-casein (55.38 \%, $38.20 \%$, respectively) is lower in comparison to the cheese produced with natural rennet $(67.54 \%, 63.93 \%$, respectively). Hayaloglu et al. (2007) reported that the type of medium used for ripening of Tulum cheese (skin or plastic barrels) has no significant influence on $\mathrm{a}_{\mathrm{s} 1}$-casein and $\beta$-casein degradation. On the other hand, in the research of Bouhezza cheese made from goat milk more intensive proteolytic degradation on $\beta$-casein was detected, which is attributed to a different production technique, where no rennet is used for coagulation, but spontaneous lactic acid fermentation. Three peptide fractions were detected $\beta$-CN (f29-209; ү1-CN), $\beta-C N$ (f106-209; ү2-CN), $\beta-C N$ (f108-209; $\gamma 3-C N$ ) as the result of plasmin activity on $\beta$-casein (Medjoudj et al., 2017b). The mentioned peptide fractions of $\beta$-casein were also detected in Bouhezza cheese made from cow's milk (Aissaoui Zitoun et al., 2012). The degradation of $\mathrm{a}_{\mathrm{S} 1}$-casein during ripening of Bouhezza cheese is explained by the enzymatic activity of catepsin D. 
After 15 days of ripening, three peptide fractions of $\mathrm{a}_{\mathrm{S} 1}$-casein appear. Two fractions disappear at $30^{\text {th }}$ and $45^{\text {th }}$ day of ripening, probably due to the degradation by peptidases of LAB. They appear again at the $64^{\text {th }}$ and $72^{\text {nd }}$ day of ripening, after adding raw goat's milk to the cheese, when the indigenous milk enzymes play their role in primary proteolysis (Medjoudj et al., 2017b). Intense proteolysis occurs during ripening of Divle Cave cheese as the content of hydrophobic and hydrophilic peptides progressively increases during ripening. The greatest increase in peptides content is observed after 60 days of ripening, which is in accordance with the results of the research of microbiota of Divle Cave cheese. After this period, mould strains began to increase both in number and in diversity, which may account for the additional proteolysis (Sarić, 2013; Ozturkoglu-Budak et al., 2016a; Ozturkoglu-Budak et al., 2018).

The overall rate of the proteolysis intensity is determined by the assessment of the secondary proteolytic changes, through the measuring of the water-soluble nitrogen fraction in the total nitrogen (WSN \%TN) and the $12 \%$-trichloroacetic acid soluble nitrogen fraction in the total nitrogen (TCA-SN \%TN). WSN \%TN values present the amount of small and medium size polypeptides, free amino acids and their solids, which are formed as a result of chymosin activity and, to a lesser extent, plasmin activity. The amount of the nitrogen fractions depends on the primary proteolytic processes of casein hydrolysis during chymosin activity and the milk proteases present at the beginning of the ripening (Lavasani et al., 2012). Casein micelles and chymosin molecules repel each other due to their negative charge. Rako et al. (2019) reported that addition of salt to the milk has an important role in the extent of secondary proteolysis due to the impact of the chymosin retention in the curd. The addition of salt to the milk during cheese production increased the ionic strength in the milk leading to a decrease in the zeta-potential and less negatively charged surfaces of casein micelles. This allows better interactions between them and chymosin molecules, which consequently increase the initial retention of chymosin in a curd (Bansal et al., 2007). Therefore, rennet is responsible for the production of WSN \%TN and to a much lower extent for the production of TCA-SN \%TN (Bansal et. al., 2010).
TCA-SN\%TN represent the amount of non-protein nitrogen and free amino acids that occur as a result of proteolytic activity of starter culture and non-starter microorganisms and, to a lesser extent, as chymosin activity (Desmazeaud et al., 1977; Addeo et al.1992; Havranek et al. 2014). Table 3 gives an overview of the secondary proteolytic changes during ripening of cheeses in animal skin. The content of WSN \%TN and TCA-SN \%TN significantly increase during ripening in the animal skin sack (Şengül et al., 2014; Tudor Kalit et al., 2014; Rako et al., 2019). According to Tudor Kalit et al. (2014) WSN \%TN increase significantly during ripening of cheese reaching the value of $18.34 \%$ after 30 days, while Rako et al. (2019) found higher values $(29.25 \%)$ for the same ripening stage. Şengül et al. (2014) reported lower levels of WSN \%TN $\left(17.80 \%\right.$ at the $90^{\text {th }}$ day of ripening) during ripening of Tulum cheese produced with microbial and calf rennet. The type of coagulant does not significantly affect the proteolysis rate. The differences in the WSN \%TN values in the above mentioned studies can be explained by the different retention of residual rennet in the curd, which is specifically seen in the case of Rako et al. (2019) research where salting of milk was conducted. Serhan et al. (2010) claim that the higher salt content in cheese can delay proteolysis at the beginning of ripening. Darfiyeh cheese is characterised by a lower content of salt and higher water content and has a higher WSN \%TN (13.16\%) after 20 days of ripening than cheese with higher salt concentration (8.95\%) and lower water content. After the $40^{\text {th }}$ day of ripening intensive proteolysis takes place in all cheeses regardless of their salt content. At the end of ripening, the Darfiyeh cheese with the lowest salt content has the highest WSN \%TN value (21.96\%), while cheeses with a higher salt content have the lowest WSN\%TN value (17.70 \% and $20.14 \%$ ), indicating an inverse relationship between proteolytic activities and the salt content in the cheese. According to the Vrdoljak et al. (2018b) the addition of probiotic cultures in production of Sir iz mišine intensifies the proteolysis. The content of WSN \%TN at the end of ripening (45 days) is less than a half ( $12 \%$ ) in comparison to cheeses manufactured by adding Lactococcus lactis (30 \%) and Lactobacillus plantarum (24\%), which results in better sensory properties and volatile compounds profile (Kostelac et al., 2020). 
Medjoudj et al. (2017b) reported that WSN \%TN content $(13.04 \%)$ at the end of the ripening $\left(64^{\text {th }}\right.$ day) of Bouhezza cheese made from raw goat's milk is significantly lower compared to the above mentioned results of Sir iz mišine, Darfiyeh and Tulum cheese research. The reason for this is coagulation of milk by the spontaneously lactic acid fermentation, not using rennet.

Residual rennet has the ability to produce mainly large-sized peptides (Desmazeaud et al., 1977) but it shows very limited ability to release free amino acid during ripening of cheese (O'Keeffe et al., 1976). Water-soluble peptides generated by chymosin activity and, to a lesser extent, plasmin activity, are further degraded by intracellular and extracellular enzymes from the starter and non-starter microflora to low molecular weight, non-protein nitrogen fractions soluble in 12\%-TCA (Addeo et al., 1992; McSweeney and Sousa, 2000). As TCA-SN \%TN values are indicators of smaller nitrogen fractions, this value is expected to increase during the ripening process (Celik and Tarakci, 2017). According to this, Serhan et al. (2010) recorded the increase in the TCA-SN \%TN value during the entire ripening period of Darfiyeh cheese. The increase in TCA-SN $\%$ TN value is in positive correlation with the WSN $\%$ TN value. At the $20^{\text {th }}$ day of ripening it amounts to $11.30 \%$ and at the $60^{\text {th }}$ day $18.28 \%$. SimilarIy, a positive correlation between WSN \%TN and TCA-SN \%TN values is found by Tudor Kalit et al. (2014), with amounts of $23.69 \%$ and $12.24 \%$ at the $60^{\text {th }}$ day of ripening, respectively. Considerably more intense secondary proteolytic changes are registered by Rako et al. (2019), which can be attributed to a significantly higher moisture content in Sir iz mišine during the ripening period and probably to the presence of autochthonous microorganism species with more intense proteolytic activity. Şengül et al. (2014) claim that the increase in the TCA-SN \%TN value in the cheese is closely related to the type of coagulant and duration of ripening. Cheese produced with Aspergillus niger protease at the $30^{\text {th }}$ and $60^{\text {th }}$ day of ripening has the lowest TCA-SN \%TN value (2\% and $5 \%$, respectively), while cheeses produced with protease Rhizomucor Miehei (3\% and $9 \%$, resepectively), and calf coagulant (3\% and $6 \%$, respectively) have higher values during this ripening period. At the end of ripening (90 days), the highest TCA-SN/TN value
(14\%) is found in cheese in which microbial coagulant from Aspergillus niger was used, while cheeses made with microbial coagulant from Rhizomucor miehei and calf rennet have lower values (12\%, 9 $\%$, respectively). In addition, the increase of TCASN \%TN values could be the result of the activity of the non-starter microorganisms, such as yeasts and moulds, which are the part of the microbial population of an animal skin.

The significant role of the animal skin as a medium for cheese ripening, in the intensity of proteolytic reactions is shown by Tudor Kalit et al. (2012). WSN \%TN and TCA-SN \%TN values are higher in 75-day matured Sir iz mišine (22.77 \% and $16.27 \%$, respectively) in comparison to the cheese ripened in a natural rind (12.36 \% and $8.21 \%$, respectively). Cheese ripened in animal skin undergoes more pronounced proteolytic changes than cheese ripened in natural rind, which is the result of anaerobic ripening conditions and the natural microflora of the skin sack (moulds and yeasts). A significant difference in the content of WSN between cheese ripened in animal skin (19.98\%) and cheese ripened in natural rind ( $13.86 \%$ ) occurs after 45 days of ripening, indicating that a more intense rate of proteolysis in the animal skin sack starts after that period.

Differences in the nitrogen fraction values between cheeses ripened in animal skin are a consequence of the different types of milk used for cheese production and the different production techniques (Table 3).

\section{Lipolysis}

The degree of lipolytic changes during cheese ripening is determined by the free fatty acids content (FFAs) and the degree of acidity. The FFA profile is variable and depends on the type of milk and its composition, manufacturing procedure and ripening conditions. Therefore, it is known that cheeses made from ewe's milk and cheeses with moulds have a more intensive lipolysis process (Svensson et al., 2006; Sarić, 2013). Due to the anaerobic conditions during ripening inside the animal skin sack and the microbial population of a skin, lipolysis is the most important biochemical process during ripening of this type of cheeses. Intensive lipolysis results in a piquant and sharp flavour, aroma and odour of cheese (Yilmaz et al., 2005; Tudor 
TABLE 3. Secondary proteolytic changes at the end of cheese ripening in animal skin

\begin{tabular}{l|l|l|l|l|l|l|l|l|l}
\hline & Darfiyeh & Tulum & Tulum & $\begin{array}{l}\text { Sir iz } \\
\text { mišine }\end{array}$ & $\begin{array}{l}\text { Sir iz } \\
\text { mišine }\end{array}$ & $\begin{array}{l}\text { Sir iz } \\
\text { mišine }\end{array}$ & $\begin{array}{l}\text { Sir iz } \\
\text { mišine }\end{array}$ & Divle Cave & Bouhezza \\
\hline $\begin{array}{l}\text { Ripening } \\
\text { duration }\end{array}$ & 60 & 120 & 90 & 30 & 60 & 75 & 45 & 120 & 64 \\
\hline WSN\%TN & 21.96 & 36.01 & 17.00 & 29.25 & 23.69 & 22.77 & 12 & 20.04 & 13.04 \\
\hline $\begin{array}{l}\text { TCA- } \\
\text { SN\%TN }\end{array}$ & 18.24 & 19.07 & 9.70 & 17.93 & 12.24 & 12.36 & - & - & - \\
\hline $\begin{array}{l}\text { Literature } \\
\text { sources }\end{array}$ & $\begin{array}{l}\text { Serhan et } \\
\text { al. (2010) }\end{array}$ & $\begin{array}{l}\text { Celik and } \\
\text { Tarakci, } \\
(2017)\end{array}$ & $\begin{array}{l}\text { Şengül } \\
\text { et al. } \\
(2014)\end{array}$ & $\begin{array}{l}\text { Rako } \\
\text { et al. } \\
(2019)\end{array}$ & $\begin{array}{l}\text { Tudor } \\
\text { Kalit et } \\
\text { al. (2014) }\end{array}$ & $\begin{array}{l}\text { Tudor } \\
\text { Kalit et } \\
\text { al. (2012) }\end{array}$ & $\begin{array}{l}\text { Vrdoljak } \\
\text { et al. } \\
\text { (2018b) }\end{array}$ & $\begin{array}{l}\text { Ozturkoglu- } \\
\text { Budak et al. } \\
\text { (2018) }\end{array}$ & $\begin{array}{l}\text { Medjoudj } \\
\text { et al. } \\
\text { (2017b) }\end{array}$ \\
\hline
\end{tabular}

WSN\%TN= Water-soluble nitrogen fraction in the total nitrogen, TCA\%TN= $12 \%$ - trichloracetic acid soluble nitrogen fraction in total nitrogen

Kalit et al., 2016; Ozturkoglu-Budak et al., 2018; Medjoudj et al., 2017a). Together with proteolysis products, FFAs directly contribute to these specific cheese properties. Besides their direct influence, FFAs are precursors in many catabolic reactions in which aromatic substances or volatile compounds such as ketones, lactones, alcohols, esters and aldehydes, are formed (McSweeney and Sousa, 2000; Collins et al., 2003).

The FFAs content is significantly higher at the end of ripening $\left(60^{\text {th }}\right.$ day) of Sir iz mišine (195.41 $\mathrm{mg} / 100 \mathrm{~g}$ cheese), in comparison to the beginning of ripening (39.08 mg/100 g cheese). According to Yilmaz et al. (2005.) lower FFAs content at the $60^{\text {th }}$ day of ripening (164.06 mg/100g cheese) in Tulum cheese could be due to the lower ripening temperature $\left(6-10^{\circ} \mathrm{C}\right)$ and different milk type for cheese production (cow's milk). Divle Cave cheese is characterised by a very intense lipolysis $(600 \mathrm{mg} / 100 \mathrm{~g}$ cheese at the $60^{\text {th }}$ day of ripening), which is attributed to the yeasts and moulds lipase activity on the skin (originating from the cave) and the presence of indigenous lipase in the raw ewe's milk. The higher content of yeasts and moulds in a layer of cheese closer to the skin, compared to cheese from the inside of the skin sack, is a consequence of yeasts and moulds growth on the skin during cheese ripening. At the end of ripening (120 th day) the FFAs content is $1200 \mathrm{mg} / 100 \mathrm{~g}$ cheese, which is in the range of FFAs content of cheeses with moulds such as Roquefort and Gorgonzola (Collins et al., 2003; Ozturkog lu-Budak et al., 2018). The mould Mucor racemosus and the yeast Yarrowia lipolytica have the highest lipolytic activity, while it is determined that Penicillium brevicompactum, Penicillium cavernicola and Penicillium olsonii have the highest proteolytic activity (Ozturkoglu-Budak et al., 2016c). The addition of microbial lipase has a significant effect on the total FFAs content in the cheese, but there is no significant effect on their composition. The increase in FFAs content is proportional to the increase of the amount of microbial lipase added; therefore, the addition of lipase could be used to accelerate the ripening process, or to develop the cheese flavour and aroma in a shorter time. The content of FFAs (184 mg/100 g cheese) in 15 days matured cheese produced with the addition of lipase $(0.11 \mathrm{~g} / \mathrm{L}$ milk) is equal to the FFAs content of 90 days matured cheese produced without the addition of lipase (Yilmaz et al., 2005). However, the use of microbial lipase in the production of cheeses with intensive lipolysis should be done very carefully, as excessive lipolysis could adversely affect consumer acceptability (Tudor Kalit et al., 2014). Pasteurization and the type of ripening medium also have a significant effect on the FFAs content. Tulum cheese made from raw goat's milk has a significantly higher content of FFAs compared to cheese made from pasteurized milk (Sert et al., 2014). Ripening in goat skin intensifies the lipolysis process in relation to the ripening in plastic barrels. Ewe's milk Tulum cheese 90 days after ripening in goat's skin contains 308 mg FFAs/100 g cheese, while the cheese ripened in plastic barrels recorded a 
considerably lower (188,60 mg FFAs/100 g cheese) lipolysis rate (Tekin and Güler, 2019). The type of rennet (natural or microbial) has no influence on the total content of FFAs, which indicates that lipolytic changes during cheese ripening are mainly related to indigenous milk lipase and microorganisms lipase.

Although cheeses ripened in animal skin have different technology of production and are made from different types of milk, at the end of ripening time, long-chain fatty acids are predominant (Tudor Kalit et al., 2014; Ozturkoglu-Budak et al., 2018; Yilmaz et al., 2005; Sert et al., 2014). At the end of the ripening of Sir iz mišine the most abundant long-chain free fatty acids are palmitic acid (C16:0), oleic acid (C18:1) and stearic acid (C18:0) (Tudor Kalit et al., 2014), which is also the case in Tulum cheese made from goat's milk (Sert et al., 2014). Predominant fatty acids in Tulum cheese made of cow's milk are C16:0, C18:1 and myristic (C14:0) fatty acids (Yilmaz et al., 2005). Similarly, fatty acids C16:0, C18:1, C18:0 and C14:0 are the most abundant FFAs in Divle Cave ewe's milk cheese (Ozturkoglu-Budak et al., 2018). Tudor Kalit et al. (2016) reported a positive correlation between the content of C 14:0, C 14:1, C 16:0, C 17:0, C 18:0, C 18:2n-6, 18:3n-3 and C 23:0 with the characteristics of cheese odour, as well as $C 8: 0, C$ 12:0, C 14:0, C 16:0, C 16:1, C 17:0, C 18:0 C 18:1n9t, C 18:3n-3, C 21:0, C 22:0 and C 23:0 with cheese flavour. The long-chain fatty acids contribute to the lower sensory score of Sir iz mišine after 60 days of ripening as precursors in the synthesis of shortchain fatty acids and alcohols, as well as an accumulation of C 4:0, C 6:0 and C 8:0 fatty acids as a result of ripening conditions and duration (Tudor Kalit et al., 2016).

The content of short-chain, medium-chain and long-chain FFAs increase during the ripening of Tulum cheese with an increase in added microbial lipase (Yilmaz et al., 2005) and it is also higher in Tulum cheese made from raw goat's milk in comparison to the cheese made from pasteurised milk (Sert et al., 2014). The use of microbial lipase in the production of Tulum cheese shows the largest relative increase in the content of short-chain fatty acids; acetic, butyric, caproic, caprylic and capric, and it is known that short-chain fatty acids play an important role in the formation of cheese flavour and aroma (Yilmaz et al., 2005). The ripening medium has a considerable influence on the FFAs composition. Tulum cheese that is ripened in the skin has a higher content of long-chain unsaturated fatty acids compared to the cheese ripened in plastic barrels and has a higher content of short-chain, medium-chain and long-chain FFAs up to the $180^{\text {th }}$ day of ripening. At the end of the ripening $\left(270^{\text {th }}\right.$ day), there is no difference in the content of medium-chain (21\%) and long-chain (74\%) fatty acids between cheeses ripened in the different material (Tekin and Güler, 2019). The type of the rennet does not have a significant effect on the content of short-chain fatty acids and saturated fatty acids. However, cheese produced by milk coagulation using natural rennet has a significantly higher content of free unsaturated fatty acids (palmitic $1.80 \%$, oleic $19.12 \%$, linoleic $3.11 \%$ and linolenic $0.40 \%$ ) compared to cheese produced by coagulation with microbial coagulant (Sengul et al., 2014). A significant difference is recorded in the content of C18:1 trans-9 fatty acid famous for its negative influence on cardiovascular system, which is three time higher in cheese ripened in skin (1200 mg/kg) compared to cheese ripened in plastic barrels $(400 \mathrm{mg} / \mathrm{kg}$ ). The reason could be found in the higher content of C18:2 and C18:3, substrates for synthesis of that fatty acid (Tekin and Guler, 2019). However, a different pattern in the relative intensity of increase in the content of short-, medium- and long-chain FFAs during ripening, can be explained by the presence of different types of lipases in different amounts, which act specifically. The lipoprotein lipase of milk, lactic bacteria acid lipase and lipases of secondary microorganisms cleave fatty acids from triglycerides molecules based on the length of their chain or their position in triglyceride (position sn-1, -2 or -3) (Yilmaz et al., 2005; Tekin and Güler, 2019).

\section{Volatile compounds}

Complex volatile and non-volatile chemical compounds, responsible for the characteristic sensory properties of cheese, are formed as a result of proteolysis, lipolysis and metabolism of lactose, lactate and citrate that take place during cheese ripening. Lactose degradation and citrate metabolism leads to the accumulation of acetaldehyde, acetate, ethanol, diacetyl, and acetoin in cheese. Diacetyl and 
acetoin compounds that give the cheese a buttery aroma are formed during citrate metabolism. Amino acids and soluble peptides, which are the result of proteolysis, significantly assist the formation of cheese texture, flavour and aroma. The breakdown of amino acids produces specific compounds that form aromas of different types of cheese (Urbach, 1997; McSweeney and Sousa, 2000). Free fatty acids obtained by the fat hydrolysis serve as precursors for the formation of ketones, primary and secondary alcohols, lactones, aldehydes and esters, compounds also responsible for the cheese flavour and aroma (Fox et al., 2000; Collins et al., 2003). Cheese flavour is concentrated in the water-soluble fraction (peptides, amino acids, organic acids and amines), while aroma is mostly concentrated in the volatile fraction (organic acids, aldehydes, amines and esters). The concentration and composition of volatile compounds directly determine the cheese aroma. Most cheeses contain the same or similar components, but in different concentrations and ratios. Therefore, the specific aroma of each type of cheese is a result of a combination of various compounds formed during ripening (Mikulec et al., 2010). Cheese flavour and aroma are also influenced by the milk type, animal feeding regime, water content and $\mathrm{pH}$ value of curd and cheese, salt content and method of salting, ripening temperature and the activity of primary and secondary microflora (Fox et al., 2000; McSweeney and Sousa, 2000; Tratnik and Božanić, 2012).

The piquant aroma and flavour of cheeses that ripen in animal skin are the result of intensive biochemical processes that take place under unique ripening conditions. Several studies have focused on the identification of volatile compounds responsible for unique aroma and flavour of cheeses that ripen in animal skin (Hayaloglu and Karabulut, 2013; Ozturkoglu-Budak et al., 2015; Ozturkoglu-Budak et al., 2016; Medjoudj et al., 2017b; Gursoy et al., 2018). Although the predominant volatile compounds are esters, acids, methyl ketones, aldehydes, alcohols, sulphur compounds and terpenes, the obtained results showed that volatile profile is specific for each cheese, which is described by the different manufacturing technology and type of milk, as well as ripening conditions and duration (Vrdoljak et al., 2018).
Most of acids present in the cheeses originate from the milk fat lipolysis or from fermentation of lactose or lactic acid, such as ethanoic, propanoic, and butanoic acids. In addition, some acids are produced by the metabolism of the amino acids Val, Leu and Ile, such as 2-methyl propanoic, 2-methyl butanoic, and 3-methyl butanoic acids, respectively (Molimard and Spinnler, 1996; Urbach, 1997). Carboxylic acids are not only aroma components as such, but can also serve as precursors for the formation of methyl ketones, alcohols, lactones, aldehydes, and esters (Collins et al., 2003). Hayaloglu et al. (2007) found a significant influence of the ripening medium on concentrations of 2-methyl propanoic, 2-methyl butanoic and 3-methyl butanoic acids in Tulum cheese. Cheeses in plastic barrels contain the highest concentrations of these acids. Hayaloglu and Karabulut (2013) mention butyric acid, acetic acid and caproic acid as the most prevalent in Divle Cave cheese but 2-methyl propanoic and 3-methyl butanoic acids were not detected. Ozturkoglu-Budak et al. (2016) reported that carboxylic acids are the major volatiles at the end of Tulum cheese ripening. Their relative amount increased until 90 days of ripening, and after that, it decreased which authors connected to the increase of mould content (Ozturkoglu-Budak et al., 2015). In Söğle Tulum cheese carboxylic acids are the third most abundant volatiles, with acetic acid as the predominant, both in cheeses made from goat milk or mixture of goat and ewe milk (Gursoy et al., 2018). In goat's milk Bouhezza cheese hexanoic acid is predominant, followed by octanoic, pentanoic, decanoic, butanoic and acetic acids. The increase of their content during ripening is probably due to the contribution of fat brought by the adding of the full-fat raw milk during the manufacturing of Bouhezza cheese between $34^{\text {th }}$ and $56^{\text {th }}$ day of ripening (Medjoudj et al., 2017a).

Cheeses ripened in animal skin sack or plastic barrel have similar aroma patterns, but the concentrations of some components are different. The concentrations of esters ethyl butanoate, ethyl hexanoate, ethyl lactate, and propyl acetate are the highest in the Tulum cheese ripened in the skin in comparison to the cheese ripened in plastic barrels. Higher concentrations of esters could be correlated to a higher concentration of alcohols in those cheeses, which leads to the higher 
rate of esterification reactions between the fatty acids and alcohols (Hayaloglu et al., 2007). Similarly, Ozturkoglu-Budak et al. (2016), Medjoudj et al. (2017a) and Gursoy et al. (2018) found that ethyl esters are the most abundant esters in Divle Cave, Bouhezza and Söğle Tulum cheese, respectively. Ethyl acetate and ethyl octanoate amounts increase in the first stage of ripening of Divle Cave cheese, which could be related to the increase in yeasts and moulds count. Their decrease at the end of ripening could be due to the decrease of alcohol content at the end of ripening (Ozturkoglu-Budak et al., 2016). Alcohols are important volatile compounds that may contribute to the flavour of the cheeses ripened in animal skin. The predominant alcohols in Tulum, Bouhezza, Divle Cave cheese and Sir iz mišine are ethanol, 3-methyl 1-butanol and 2-butanol (Hayaloglu et al. 2007; Medjoudj et al. 2017b; Ozturkoglu-Budak et al., 2016; Kostelac et al., 2020), while in Darfiyeh cheese the most abundant are 2-propanol and 1-octanol (Serhan et al., 2010). Aldehydes may contribute to the flavour of cheese because of their low perception thresholds and are characterized by herbaceous and green-grass-like aroma (Molimard and Spinnler, 1996; Hayaloglu et. al., 2007). They are not accumulated in cheese due to their transition properties by conversion into alcohols, and oxidization to their corresponding acids (Molimard and Spinnler, 1996; Munoz et al., 2003). 3-methyl butanal is one of the three predominant aldehydes in cheese ripened in the skin sack (Hayaloglu et. al., 2007; Ozturkoglu-Budak et al., 2016; Serhan et al., 2010., Medjoudj et al. 2017a; Hayaloglu and Karabulut, 2013).

Methyl ketones are formed by enzymatic oxidation of free fatty acids to $\beta$-ketoacids and their consequent decarboxylation to methyl ketones (McSweeney and Sousa, 2000). Therefore their content increase during ripening (Ozturkoglu-Budak et al., 2016; Medjoudj et al. 2017a). Hayaloglu et al. (2007) reported a positive correlation between methyl ketones amount and the content of yeasts and moulds, suggesting their role in the formation of methyl ketones in this type of cheeses. In addition, the ripening material (skin or plastic) has a significant impact on the methyl ketones profile. In Divle cave cheese the most abundant methyl ketones are 2-butanone, 2-pentanone and 2-heptanone (Ozturkoglu-Budak et al., 2016), in Darfiyeh 2-heptanone, 2-nonanone and 2-undecanone, in Bouhezza 2-heptanone, 2-nonanone, 2-propanone (Medjoudj et al., 2017a) suggesting that catabolism reactions are specific for each cheese due to the different composition of these types of cheeses, microbiological characteristics and ripening conditions. A good example is the presence of 2-butanone in Divle Cave cheese and Söğle Tulum cheese (Ozturkoglu-Budak et al., 2016; Gursoy et al., 2018), as 2-butanone derives from diacetyl, which is produced by the metabolism of lactose or citrate.

Terpenes in milk originate from plants in the feed mixture or pasture (Curioni and Bosset, 2002), and are important for determining the geographical origin of a cheese as their content in forage varies greatly according to the plant species (Cornu et al., 2005; Bontinis et al., 2012). Ripening material (skin or plastic) has no role in the formation of terpenes in cheeses; as the cheese milk is obtained from the same area (Hayaloglu et al., 2007). Ripening process also does not affect the terpenes content in cheese (Ozturkoglu-Budak et al., 2016).

\section{Microbiological characteristics}

The majority of cheeses ripened in animal skin are traditionally made from raw milk, and their flavour and aroma are the result of a combined action of non-starter lactic acid bacteria and other bacteria, yeasts and moulds originating from the raw milk, but also from the environment during cheese ripening. With the activity of complex enzymatic system of microorganisms during cheese ripening under specific conditions (in the animal skin skin), protease and lipases in the first place, cheese acquires specific sensory properties (Mullan et. al., 2014; Frece et al., 2016; Ozturkoglu-Budak et al., 2016a). The studies of the natural microbial population of cheeses ripened in animal skin has shown that the lactic acid bacteria of the genera Lactococcus, Enterococcus, Lactobacillus and Streptococcus dominate, as well as yeasts and moulds. As a result of their metabolism, they form aromatic compounds that significantly influence the ripening process and the development of cheese flavour and aroma (Oksuztepe et al., 2005; Cakmakci et al., 
2008; Serhan et al., 2009; Kaić et al., 2016; Ozturkoglu- Budak et al., 2018).

During ripening of Sir iz mišine (75 days) lactococci are present in the highest number, followed by enterococci and lactobacilli. A total of 105 lactococci, 90 enterococci and 90 lactobacilli species are isolated (Kaić et al., 2016). Of the isolated lactid acid bacteria in Darfiyeh cheese, Enterococcus species are the most common (Serhan et al., 2009). Similarly, Lactobacillus and Lactococcus species are the predominant population at the beginning of ripening of Tulum cheese, but after 3 months of ripening the number of Enterococcus species bacteria increases significantly. This is a consequence of their good tolerance to the lower $\mathrm{pH}$ and the high salt concentration in the cheese. Specifically, the number of Lactococcus lactis species decreases significantly during the ripening process (Cakmakci et al., 2008). In Darfiyeh cheese, Lactococcus lactis subsp. lactis is isolated as the dominant variety. As Darfiyeh cheese can contain $9.5 \%$ salt at the end of ripening, Lactococcus lactis subsp. cremoris is not isolated due to inability to grow in conditions of high salt concentration. The inability of micrococcus, aerobic microorganisms, to grow is the proof of anaerobic conditions during cheese ripening in animal skin. Among lactobacilli, the most common is Lactobacillus plantarum that is well tolerant to the lower pH and the high salt content (Serhan et al., 2009; Serhan et al., 2010).

The microbiological characteristics of cheeses ripened in the skin in comparison to those which ripen in plastic barrels, are different in number of yeasts, moulds and lactic acid bacteria. Tulum cheese ripened in animal skin has a higher number of yeasts and moulds compared to Tulum cheese ripened in plastic or ceramic barrels, which indicates a better skin permeability than other materials (Hayaloglu et al., 2007; Ceylan et al., 2007) and a lower number of lactic acid bacteria (Oksuztepe et al., 2005). Of 16 isolated moulds, 12 belong to Penicillium roqueforti and 4 to Geotrichum candidum. Although Penicillium roqueforti is an anaerobic microorganism, it is shown that it can tolerate some lower levels of oxygen in cheese inside the animal skin sack. Its ability to produce mycotoxins, as a safety aspect for human health, has also been demonstrated (Erdogan et al., 2003). The number of yeasts and moulds increase during Tulum cheese ripening, while the number of coliform bacteria decreases. The number of yeasts and moulds at the $30^{\text {th }}$ day of Tulum cheese ripening is between 5.20 and $6.04 \mathrm{log} \mathrm{cfu} / \mathrm{g}$. The highest values of yeasts and moulds are reached at the end of the 150- day ripening period and are between 6.82 and $7.57 \mathrm{log}$ $\mathrm{cfu} / \mathrm{g}$. The number of coliform bacteria at the $30^{\text {th }}$ day of Tulum cheese ripening is $5.00 \mathrm{log} \mathrm{cfu} / \mathrm{g}$, and at the end of 150 days of ripening, their number is 0 log cfu/g. A decrease in the number of coliform bacteria can be the result of the decrease in $\mathrm{pH}$ value and water activity, higher content of salt and increase in the number of yeasts and moulds (Hayaloglu et al., 2007). Ozturkoglu- Budak et al. (2018) investigated the microbiological properties of Divle Cave cheese in different parts of the cheese, next to the skin and inner part of the cheese. During ripening in cheese from the inner part, the number of Lactobacillus species is higher than in the cheese next to the skin, which may be explained by the competition for nutrients with yeasts and moulds, which are a dominant microbial population of the skin. For this reason the number of yeasts and moulds in cheese near to the skin (7.6 log $\mathrm{cfu} / \mathrm{g})$ is higher compared to the inner part of the cheese (3.3 log cfu/g), which can be further associated with anaerobic conditions in the inner part of skin and the lower humidity. In addition, at the end of the ripening of Divle Cave cheese, the number of coliform bacteria, staphylococci and enterobacteria, indicators of inadequate hygienic conditions in cheese production, are not present after 90 days of ripening, regardless of the part of cheese, inner part or near the skin.

In Bouhezza cheese, the yeasts and moulds number remain constant during first 3 weeks with levels between 3 and $4 \log \mathrm{cfu} / \mathrm{g}$. At the $4^{\text {th }}$ week, it reached the number $6.45 \mathrm{log} \mathrm{cfu} / \mathrm{g}$, then decreased during the three following weeks and finally reached $6.53 \mathrm{log} \mathrm{cfu} / \mathrm{g}$ at the $8^{\text {th }}$ week. Authors reported that the increase is probably due to the favourable acidic conditions (low pH) and salt contents for yeasts and moulds growth (Medjoudj et al., 2017a). Due to the permeability of the animal skin, growth of yeasts and moulds is more pronounced in cheese ripened in animal skin than in cheese ripen in plastic barells (Hayaloglu et al., 2007). 


\section{Conclusion}

In the year 2010 the manuscript An overview of researches on cheeses ripening in animal skin (Tudor Kalit et. al, 2010) was based on several studies, most of them about basic chemical composition and physical properties of Herzegovinian Sir iz mijeha and Croatian Sir iz mišine and the few about biochemical changes during ripening of Turkish Tulum cheese. Meanwhile, the specific and complex biochemical changes that occur during ripening of cheeses in animal skin sack have become of great interest to researchers, and numerous studies were conducted. Therefore, this review compiles more data and knowledge for better understanding of biochemical changes during ripening of cheeses in animal skin.
There is a phrase saying Age is something that does not matter, unless you are a cheese (Tunick, 2014), but in the case of cheeses which ripen in animal skin the duration and conditions of ripening process should be carefully managed due to their strong taste, flavour and aroma. They originate from intensive lipolysis and proteolysis as a result of specific anaerobic conditions inside the skin sack, autochthonous microorganisms from raw milk and skin, as well as manufacturing technology. As biochemical changes during ripening directly influence sensory attributes of cheese, which determine consumer preference, this review could provide practical data for cheesemakers to prevent negative consequences of overly intensive biochemical changes during cheese ripening, and so improve the quality of this kind of cheeses.

\section{Biokemijske promjene tijekom zrenja sireva u životinjskoj koži}

\section{Sažetak}

Sirevi koji zriju u životinjskoj koži proizvode se u nekoliko zemalja svijeta: Sir iz mišine (Hrvatska), Sir iz mijeha (Bosna i Hercegovina te Crna Gora), Tulum i Divle Cave (Turska), Bouhezza (Alžir) i Darfiyeh (Libanon). Izražen i pikantan okus i aroma ovih sireva potječu od intenzivnih procesa lipolize i proteolize koje su posljedica anaerobnih uvjeta u životinjskoj koži, autohtonih mikroorganizmima iz sirovog mlijeka i kože, kao i tehnološkog postupka proizvodnje. Specifične i kompleksne biokemijske promjene koje se odvijaju tijekom zrenja sireva u životinjskoj koži predmet su interesa znanstvenika, te su tako provedena brojna istraživanja ove vrste sireva u posljednjem desteljeću. Stoga, cilj ovog rada je prikazati specifičnosti proteolitičkih i lipolitičkih promjena tijekom zrenja sireva u životinjskoj koži, koje rezultiraju i karakterističnim profilom hlapljivih tvari. Povrh toga rad daje pregled postupaka proizvodnje i fizikalno-kemijskih svojstava sireva s obzirom na njihovu izravnu povezanost s biokemijskim reakcijama tijekom zrenja sira u koži. S obzirom da biokemijske reakcije izravno utječu na senzorska svojstva sira, što može odrediti preferencije potrošača, ovaj pregledni rad sirarima može dati praktične informacije u cilju prevencije negativnih posljedica intenzivnih biokemijskih reakcija tijekom zrenja sira, te time poboljšati kvalitetu ove vrste sireva.

\section{Ključne riječi: životinjska koža, zrenje sira, biokemijske promjene, proteoliza, lipoliza, hlapljive tvari}


1. Addeo, F., Chianese, L., Salzano, A., Sacchi, R., Cappuccio, U., Ferranti, P., Malorni, A. (1992): Characterization of the $12 \%$ trichloroacetic acid insoluble oligopeptides of Parmigiano-Reggiano cheese. Journal of Dairy Research 59, 401-411. https://doi.org/10.1017/s0022029900030673

2. Aissaoui Zitoun, O., Benatallah, L., Hannachi Ghennam, E., Zidoune, M.N. (2011): Manufacture and characteristics of the traditional Algerian ripened bouhezza cheese. Journal of Food, Agriculture \&) Environment 9 (2), 96-100.

3. Aissaoui Zitoun, O., Pediliggieri, C., Benatallah, L., Lortal, S., Licitra, G., Zidoune, M.N., Carpino, S. (2012): Bouhezza, a traditional Algerian raw milk cheese, made and ripened in goatskin bags. Journal of Food, Agriculture $\odot$ Environment 10 (2), 289-295.

4. Akpinar, A., Yerlikaya, O., Kinik, O., Korel, F., Kahaman, C., Uysal, H.R. (2017): Some physicochemical characteristics and aroma compounds of Izmir tulum cheese produced with different milk types. Ege Üniversity Journal of Agriculture Faculty 54 (1), 27-35. https://doi.org/10.20289/zfdergi.297939

5. Bansal, N., Fox, P.F., McSweeney, P.L.H. (2007): Factors affecting the retention of rennet in cheese curd. Journal of Agricultural and Food Chemistry 55, 9219-9225. https://doi.org/10.1021/jf071105p

6. Bansal, N., Piraino, P., McSweeney, P.L.H. (2010): Determination of proteolysis in cheese. In: Handbook of Dairy Food Analysis, eds. Nollet, L.M.L. and Toldrá, F., CRC Press, Taylor \& Francis Group, 405-426. https://doi.org/10.1201/9781420046328-25

7. Barukčić, I., Tudor Kalit, M. (2019): Origin, production and Specificities of Croatian Traditional Cheeses. In: Cheeses around the world - Types, production, properties and cultural and nutritional relevance, eds. Guine P.F.R., Correia M.R.P. and Ferrao, A., New York, Nova Science Publishers, 153182.

8. Bijeljac, S. (2004): Sir iz mijeha. Udruga "Pramenka”, Mostar, Bosna i Hercegovina.

9. Bijeljac, S., Sarić, Z. (2005): Autohtoni mliječni proizvodi sa osnovama sirarstva. Poljoprivredni Fakultet Univerziteta u Sarajevu, Sarajevo, Bosna i Hercegovina.

10. Bontinis, T.H.G., Mallatou, H., Pappa, E.C., Massouras, T.H., Alichanidis, E. (2012): Study of proteolysis, lipolysis and volatile profile of a traditional Greek goat cheese (Xinotyri) during ripening. Small Ruminant Research 105, 193-201. https://doi.org/10.1016/j.smallrumres.2012.01.003

11. Cakmakci, S., Dagdemir, E., Hayaloglu, A.A., Gurses, M., Gundogdu, E. (2008): Influence of ripening container on the lactic acid bacteria population in Tulum cheese. World Journal of Microbiology and Biotechnology 24, 293-299. https://doi.org/10.1007/s11274-007-9470-z

12. Celik, O. F., Tarakci, Z. (2017): The effects of starter cultures on chemical, biochemical and sensory properties of low-fat Tulum cheeses during ripening. International Journal of Dairy Technology 70, 1-9. https://doi.org/10.1111/1471-0307.12377
13. Ceylan, Z.G., Caglar, A., Cakmakci, S. (2007): Some physicochemical, microbiological and sensory properties of tulum cheese produced from ewe's milk via modified method. International Journal of Dairy Technology 60, 191-196. https://doi.org/10.1111/j.1471-0307.2007.00326.x

14. Colak, H., Hampikyan, H., Bingol, E.B., Ulusoy, B. (2007): Prevalence of $\mathrm{L}$. monocytogenes and Salmonella spp. in Tulum cheese. Food Control 18, 576-579. https://doi.org/10.1016/j.foodcont.2006.02.004

15. Collins, Y.F., McSweeney, P.L.H., Wilkinson, M.G. (2003): Lipolysis and free fatty acid catabolism in cheese: a review of current knowledge. International Dairy Journal 13, 841-866. https://doi.org/10.1016/s0958-6946(03)00109-2

16. Desmazeaud, M.J., Gripon, J.C. (1977): General mechanism of protein breakdown during cheese ripening. Milchwissenschaft 32, 731-734.

17. Dozet, N., Adžić, N., Stanišić, M., Živić, N. (1996): Autohtoni mliječni proizvodi. Poljoprivredni institut, Podgorica i Silmir, Beograd.

18. Durlu Ozkaya, F., Gün, I. (2016): Cheese culture in Anatolia, ICANAS, International Congress of Assian and North African Studies, 10-15.09.2017, Ankara/Turkey, 485-506.

19. Erdogan, A., Gurses, M., Sert, S. (2003): Isolation of moulds capable of producing mycotoxins from blue mouldy Tulum cheeses produced in Turkey. International Journal of Food Microbiology 85, 83-85. https://doi.org/10.1016/s0168-1605(02)00485-3

20. Fox, P.F., Guinee T.P., Cogan, T.M., McSweeney, P.L.H. (2000): Cheese flavour. In: Fundamentals of cheese science, ed. Colilla, J., Aspen Publishers Gaithersburg, Maryland, 282-303. https://doi.org/10.1007/978-1-4899-7681-9_13

21. Frece, J., Vrdoljak, M., Filipčić, M., Jelić, M., Čanak I., Jakopović, Ž., Pleadin, J., Gobin, I., Landeka Dragičević, T., Markov, K. (2016): Microbiological quality and variability of natural microbiota in Croatian cheese maturin in lambskin sacks. Food Technology and Biotechnology 54 (2), 129-134. https://doi.org/10.17113/ftb.54.02.16.4418

22. Gün, I.., Guzel-Seydim, Z. (2011): Tulum cheese produced in our country and some properties. Journal of Milk World, 56-59.

23. Gün, ì. (2015): Determination of characteristics of animal skins of different breeds, genders and ages and investigation of its effect on Tulum cheese, TUBITAK 3501 project, Project No. 1120536, 223.

24. Gursoy, O., Kücükcetin, A., Gökce, Ö., Ergin, F., Kocatürk, K. (2018): Physicochemistry, microbiology, fatty acids composition and volatile profile of traditional Söğle tulum (goat's skin bag) cheese. Anais da Academia Brasileira de Ciências 90 (4), 3661-3674. https://doi.org/10.1590/0001-3765201820180310

25. Güler, Z., Uraz, T. (2003): Proteolytic and lipolytic composition of Tulum cheese. Milchwissenschaft 58 (9/10), 502-505. 
26. Harmancıoglu, M. (1998): Leather Chemistry, Ege University, Agriculture Faculty Publications, 533, Bornova, İmir/Turkey.

27. Havranek, J., Kalit, S., Antunac, N., Samaržija, D. (2014): Sirarstvo, Hrvatska mljekarska udruga, Zagreb.

28. Hayaloglu, A.A., Cakmakci, S., Brechany, E.Y., Deegan, K.C., McSweeney, P.L.H. (2007): Microbiology, biochemistry and volatile composition of Tulum cheese ripened in goat's skin or plastic bags. Journal of Dairy Science 90, 11021121. https://doi.org/10.3168/jds.s0022-0302(07)71597-7

29. Hayaloglu, A.A., Ozer, B. (2011): Ripening in cheese, Basics of cheese science, Sidas Publishers, İzmir, 173209.

30. Isleyici, O., Sancak, Y.C., Tuncay, R.M. (2018): Divle Tulum cheese, Van Veterinery Journal 29 (2), 119-124.

31. Kaić, D., Skelin, A., Mrkonjić Fuka, M., Kalit, S., Tudor Kalit, M., Redžepović, S. (2016): Prirodna mikrobna populacija u Siru iz mišine. International Symposium on Agriculture. Opatija, Croatia, 697-700.

32. Kalit, S. (2016): Sir iz mišine. In: The Oxford Companion to Cheese, ed. Donnelly C., Oxford University Press, New York, 657-658 https://doi.org/10.1093/acref/9780199330881.001.0001

33. Kamber, U. (2008): The Traditional Cheeses of Turkey: Cheeses Common to All Regions. Food Reviews International 24 (1), 1-38. https://doi.org/10.1080/87559120701761833

34. Koçak, C., Gursel, A., Avsar, Y.K., Semiz, A. (1995): Effect of lipase enzyme (Palatase M 200L) on the ripening of skin (Tulum) cheese, Egyptian Journal of Dairy Science 23, 43-52.

35. Kostelac, D., Vrdoljak M., Markov, K., Delaš, I., Jug, T., Gajdoš Kljusurić, J., Jakopović, Ž., Čanak, I., Jelić, M., Frece, J. (2020). SPME-GC-MS and multivariate analysis of sensory properties of cheese in a sack matured with probiotic starter cultures. Food Technology and Biotechnology 58 (2), 128-137. https://doi.org/https://doi.org/10.17113/ ftb.58.02.20.6439

36. Lavasani, A.R.Z., Ehsani, M.R., Mirdamadi, S., Mousavi, M.A.E.Z. (2012): Changes in physicochemical and organoleptic properties of traditional Iranian cheese Lighvan during ripening. International Journal of Dairy Technology 65, 64-70. https://doi.org/10.1111/j.1471-0307.2011.00724.x

37. Lešić, T., Pleadin, J., Krešić, G., Vahčić, N., Markov, K., Vrdoljak, M., Frece, J. (2016): Chemical and fatty acid composition of cow and sheep milk cheeses in a lamb skin sack. Journal of Food Composition and Analysis 46, 70-77. https://doi.org/10.1016/j.jfca.2015.11.007

38. McSweeney, P.H.L. (2004): Biochemistry of cheese ripening. International Journal of Dairy Technology 57 (2/3), 127-144. https://doi.org/10.1111/j.1471-0307.2004.00147.x

39. McSweeney, P.L.H., Sousa, M.J. (2000): Biochemical pathways for the production of flavour compounds in cheeses during ripening: A review. Le Lait 80 (3), 293-324. https://doi.org/10.1051/lait:2000127
40. Medjoudj, H., Aouar, L., Zidoune, M.N., Hayaloglu A.A. (2017a): Proteolysis, microbiology, volatiles and sensory evaluation of Algerian traditional cheese Bouhezza made using goat's raw milk. International Journal of Food Properties 20 (3), 3246-3265. https://doi.org/10.1080/10942912.2017.1375515

41. Medjoudj, H., Zidoune, M.N., Hayaloglu, A.A. (2017b): Proteolysis and volatile profile in the Algerian traditional Bouhezza cheese made using raw goat's milk. International Journal of Food Properties, 20 (8), 1876-1893. https://doi.org/10.1080/10942912.2016.1222588

42. Mullan, W.M.A (2014): Starter cultures: Importance of selected genera. In: Encyclopedia of Food Microbiology, $2^{\text {nd }}$ edition, eds. Batt, C. and Batt, A.C., Oxford Academic Press, 515-521. https://doi.org/10.1006/rwfm.1999.1515

43. Munoz, N., Ortigosa, M., Torre, P., Izco, J.M. (2003): Free amino acids and volatile compounds in an ewe's milk cheese as affected by seasonal and cheese-making plant variations. Food Chemistry 83, 329-338.

https://doi.org/10.1016/s0308-8146(03)00133-x

44. Oksuztepe, G., Patir, B., Calicioglu, M. (2005): Identification and distribution of lactic acid bacteria during the ripening of Savak Tulum cheese. Turkish Journal of Veterinary and Animal Sciences 29, 873-879.

45. Ozturkoglu-Budak, S., Aykas, D.P., Kocak, C., Dönmez, S., Gursoy, A., de Vries, R.P., Bron, P.A. (2018): Temporal microbiota and biochemical profiles during production and ripening of Divle Cave cheese. International Journal of Dairy Technology 71 (1), 99-106.

https://doi.org/10.1111/1471-0307.12493

46. Ozturkoglu-Budak, S., Figge, M.J., Houbraken, J., de Vries, R.P. (2016a): The diversity and evolution of microbiota in traditional Turkish Divle Cave cheese during ripening. International Dairy Journal 58, 50-53 https://doi.org/10.1016/j.idairyj.2015.09.011

47. Ozturkoglu-Budak, S., Gursoy, A., Aykac, D.P., Koçak, C., Dönmez, S., de Vries, R.P., Bron, P.A. (2016b): Volatile compound profiling of Turkish Divle Cave cheese during production and ripening. Journal of Dairy Science 99, 5120-5131. https://doi.org/10.3168/jds.2015-10828

48. Ozturkoglu-Budak, S., Wiebenga, A., Bron, P. A., de Vries, R. P. (2016c). Protease and lipase activities of fungal and bacterial strains derived from an artisanal taw ewe's milk cheese. International Journal of Food Microbiology 237, 17-27. https://doi.org/10.1016/j.ijfoodmicro.2016.08.007

49. Rako, A., Tudor Kalit, M., Rako, Z., Petrović, D., Kalit, S. (2019): Effect of composition and proteolysis on textural characteristics of Croatian cheese ripen in a lamb skin sack (Sir iz mišine). Mljekarstvo 69 (1), 21-29. https://doi.org/10.15567/mljekarstvo.2019.0102

50. Samardzic, S., El Bilali, H., Bajramovic, S., Kanlic, V., Ostojic, A., Berjan, S., Savkovic, A. (2014): Cheese in a Sack: Exploring History, Production Area and Production Process of a Typical Herzegovinian Product. International Journal of Environment and Rural Development 5 (2), 74-79.

51. Sari, O. (1996): Lectures notes of leather analysis and quality control, Ege University, Engineering Faculty, Leather Technology Department, Bornova / İzmir, Turkey (not pressed). 
52. Sarić, Z. (2013): Yeasts and moulds as cheese contaminants. In: Cheese ripening - Quality, Safety and Health Aspects, ed. Anderson de Souza, S. and Bernadette D.G.M.F., New York, Nova Science Publishers, 167-194.

53. Şengül, M., Erkaya, T., Dervişoğlu, M., Aydemir, O., Gül, O. (2014): Compositional, biochemical and textural changes during ripening of Tulum cheese made with different coagulants. International Journal of Dairy Technology 67, 373-383. https://doi.org/10.1111/1471-0307.12120

54. Serhan, M., Mattar, J. (2017): The Goat Dairy Sector in Lebanon. 381-396. https://www.intechopen.com/books/ goat-science/the-goat-dairy-sector-in-lebanon (accessed: 23.05.2019).

55. Serhan, M., Cailliez-Grimal, C., Borges, F., Revol-Junelles, A-M., Hosri, C., Fanni, J. (2009): Bacterial diversity of Darfiyeh, Lebanese artisanal raw goat's milk cheese. Food Microbiology 26, 645-652. https://doi.org/10.1016/j.fm.2009.04.012

56. Serhan, M, Linder, M., Hosri, C., Fanni, J. (2010): Changes in proteolysis and volatile fraction during ripening of Darfiyeh, a Lebanese artisanal raw goat's milk cheese. Small Ruminant Research 90, 75-82. https://doi.org/10.1016/j.smallrumres.2010.01.008

57. Sert, D., Akin, N., Aktumsek, A. (2014): Lipolysis in Tulum cheese produced from raw and pasteurized goats' milk during ripening. Small Ruminant Research 121, 351-360. https://doi.org/10.1016/j.smallrumres.2014.06.006

58. Simsek, O., Gursoy, O., Hazır Dalca, S., Yılmaz, Y. (2016): Autolysis in lactic acid bacteria and its importance in cheese technology. Academic Food Journal 14 (3), 293 301.

59. Sousa, M. J., Ardo, Y., McSweeney, P.L.H. (2001): Advances in the study of proteolysis during cheese ripening. International Dairy Journal 11, 327-345. https://doi.org/10.1016/s0958-6946(01)00062-0

6o. Svensson, I., Hernandez, I., Virto, M., de Renobales, M. (2006): Determination of lipase activity in cheese using trivalerin as substrate. International Dairy Journal 16, 423-443.

https://doi.org/10.1016/j.idairyj.2005.06.004

61. Tekin, A., Guler, Z. (2019). Glycolysis, lipolysis and proteolysis in raw sheep milk Tulum cheese during production and ripening: Effect of ripening materials. Food Chemistry 286,160-169. https://doi.org/10.1016/j.foodchem.2019.01.190
62. Tudor Kalit, M., Buntić, I., Morone, G., Delaš, I., Kalit S. (2016): The content of free fatty acids in relation to electronic nose sensors responses and sensory evaluation of cheese in a lamb skin sack (Sir iz mišine) throughout ripening. Mljekarstvo 66 (1), 26-33. https://doi: 10.15567/mljekarstvo.2016.0103

63. Tudor Kalit, M., Kalit, S., Delaš, I., Kelava, N., Karolyi, D., Kaić, D., Vrdoljak, M., Havranek J. (2014): Changes in the composition and sensory properties of Croatian cheese in a lamb skin sack (Sir iz misine) during ripening. International Journal of Dairy Technology 67, 255-264. https://doi.org/10.15567/mljekarstvo.2016.0103

64. Tudor Kalit, M., Kalit, S., Havranek J. (2010): An overview of researches on cheeses ripening in animal skin. Mljekarstvo 60 (3), 149-155.

65. Tudor Kalit, M., Kalit, S., Kelava, N., Havranek J. (2012): Physicochemical differences between Croatian cheese matured in a lamb skin sack (Sir iz misine) and cheese matured in a rind throughout ripening. International Journal of Dairy Technology 65 (4). 555-560. https://doi.org/10.1111/j.1471-0307.2012.00851.x

66. Tunick M.H. (2014): The science of cheese. Oxford University Press, UK.

67. Upadhyay, V.K., McSweeney, P.L.H., Magboul, A.A.A., Fox, P.F. (2004): Proteolysis in Cheese during Ripening. In: Cheese: Chemistry, Physis and Microbiology - Third edition, General aspects, eds. Fox, P. F., McSweeny, P.L.H., Cogan, T.M. and Guinee, T.P., Elsevier academic press, London, UK, 391-393. https://doi.org/10.1016/s1874-558x(04)80076-9

68. Vrdoljak, M., Mikulec, N., Markov, K,. Kalit, S., Frece, J. (2018): Aromatic compounds of cheese ripening in animal skin: An overview. Journal of Central European Agriculture 19 (2), 318-334.

https://doi.org/10.5513/jcea01/19.2.2154

69. Vrdoljak, M., Tudor Kalit, M., Kalit, S., Ljubičić, I., Radeljević, B., Frece, J. (2018b): Influence of the probiotic cultures on proteolysis patterns of Croatian cheese in lamb sack. NUTRICON Congress, June 13-15, Ohrid, Macedonia.

70. Watson, R. (2016): Tulum. In: The Oxford Companion to Cheese, ed. Donnelly C., Oxford University Press, New York, 731-732. https://doi.org/10.1093/acref/9780199330881.001.0001

71. Yilmaz, G., Ayar, A., Akin, N. (2005): The effect of microbial lipase on the lipolysis duringthe ripening of Tulum cheese. Journal of Food Engineering 69, 269-274. https://doi.org/10.1016/j.jfoodeng.2004.08.017 